\title{
EFEITOS METAFÓRICOS E HETEROGENEIDADE NO DISCURSO RELIGIOSO DE MEMBROS DA ASSEMBLEIA DE DEUS: UMA ANÁLISE DISCURSIVA
}

\author{
DALEXON SÉRGIO DA SILVA ${ }^{1}$ \\ NADIA PEREIRA GONÇALVES DE AZEVEDO²
}

\author{
Programa de Pós-Graduação em Ciências da Linguagem - UNICAP \\ Universidade Católica de Pernambuco (UNICAP) \\ Rua do Príncipe, 526 - 50050-900 - Boa Vista, Recife-PE - Brasil \\ dalexon@uol.com.br ; nadiaazevedo@gmail.com
}

\begin{abstract}
Resumo. Este trabalho pretende analisar o discurso religioso de membros da Igreja Evangélica Assembleia de Deus da convenção de Abreu e Lima, cidade da região metropolitana do Recife, em Pernambuco. Assim, à luz da perspectiva teórica e dos procedimentos analíticos da Análise do Discurso de linha francesa $(A D)$, este artigo mobiliza o conceito de efeito metafórico $e$ de heterogeneidade discursiva para analisar o discurso de dois membros da igreja (crentes assembleianos).
\end{abstract}

Palavras-chave: discurso religioso; efeito metafórico; heterogeneidade discursiva.

\begin{abstract}
This work aims to examine the religious discourse of members of the Evangelical Church Assembly of God from the convention in Abreu e Lima, city of the metropolitan area of Recife, Pernambuco. Based on the theoretical perspective and analytical procedures of the French Discourse Analysis (AD), this article mobilizes the concept of metaphorical effect and discursive heterogeneity in order to analyze the discourse of two members of the church (Assembly believers).
\end{abstract}

Keywords: religious discourse; metaphoric effect; discursive heterogeneity.

\section{Introdução}

O interesse pelo estudo do discurso religioso da Igreja Evangélica Assembleia de Deus se deu quando o primeiro autor realizou a docência em sala de aula com alunos do Ensino Fundamental e Médio da rede pública municipal e estadual. Nesta ocasião, manteve contato com muitos estudantes que eram membros da Igreja Evangélica Assembleia de Deus da convenção de Abreu e Lima, o que lhe despertou a atenção por já perceber no discurso desses sujeitos a presença de um interdiscurso cristalizado, com forte presença de metáforas, por exemplo: "a gente tá no deserto mesmo", ou, "eu sou um

\footnotetext{
${ }^{1}$ Doutorando em Ciências da Linguagem no Programa de Pós-Graduação em Ciências da Linguagem da Universidade Católica de Pernambuco (UNICAP).

2 Doutora em Letras (UFPB). Docente no Programa de Pós-Graduação em Ciências da Linguagem da Universidade Católica de Pernambuco (UNICAP).
} 
crente de fogo". Tais discursos inquietaram o primeiro autor, aguçando-lhe a curiosidade. Por conta disso, o desejo de elaborar este trabalho buscando responder às seguintes indagações:

Como o discurso religioso desses sujeitos assembleianos significa?

Que efeitos metafóricos são produzidos a partir do que há em comum entre os membros dessa igreja?

Com esse intento, este trabalho investigativo destinou-se a analisar a presença dos efeitos metafóricos e da heterogeneidade discursiva num corpus constituído pelo discurso religioso de 2 (dois) sujeitos envolvidos na pesquisa, a saber, dois crentes membros da Igreja Evangélica Assembleia de Deus da convenção de Abreu e Lima, cidade localizada na região metropolitana da cidade do Recife, no estado de Pernambuco, Brasil. Este artigo está organizado de forma a apresentar o trabalho ao leitor: na introdução, justificando-o e marcando problematizações e objetivos. Depois se pretendeu situar, brevemente, algumas considerações teóricas acerca da Igreja Evangélica Assembleia de Deus; em seguida, procede-se à discussão da teoria e procedimento analítico, suporte do trabalho, a Análise do Discurso de linha francesa, tal como delineada por Pêcheux e desenvolvida, no Brasil, por Orlandi e seguidores. Em seguida, pretendeu-se evidenciar o percurso metodológico do trabalho, para, finalmente, trazer à discussão o corpus discursivo dos sujeitos em estudo, focando no aspecto dos efeitos metafóricos e da heterogeneidade discursiva. Por último, apresenta-se as considerações finais.

\section{A constituição histórica do discurso religioso na igreja evangélica Assembleia de Deus}

No início do séc. XX houve uma mudança de paradigmas no segmento protestante. Os Estados Unidos da América vivenciavam o que se convencionou chamar de avivamento pentecostal, tendo seu início na Califórnia. Contudo, foi a igreja Batista dos Estados Unidos das Américas, mais precisamente, de Chicago, que enviou dois missionários suecos, Gunnar Vingren e Daniel Berg, ao Brasil.

O ano era 1910, ou mais precisamente, conforme Costa (1985), 19 de novembro de 1910. Nesta data, o Brasil viria a conhecer os pioneiros de um movimento religioso que se consolidaria como o Movimento Pentecostal no Brasil, no qual passaria, com o transcorrer dos anos, a se firmar e ostentar-se como o movimento evangélico que concentra o maior número de fiéis falantes de língua portuguesa em território brasileiro.

Gunnar Vingren e Daniel Berg foram dois missionários suecos que embarcaram num navio, em Nova Iorque, rumo às terras paraenses. Ambos afirmavam estarem inspirados pelo Espírito Santo para enunciarem a partir da posição-sujeito de evangelistas, que tinham por objetivo trazer ao povo brasileiro o conhecimento acerca do movimento pentecostal que se aflorava, naquela época, na Suécia e nos Estados Unidos da América.

Ao pisarem no solo de Belém, esses dois suecos iniciaram um processo de catequização da população belemita, afirmando que era possível receber a cura divina e o batismo com fogo, no Espírito Santo. Eles usavam a Bíblia como elemento de persuasão 
referencial, como suporte para produzir o efeito de sentido de convencimento e de adesão aos seus ensinamentos pentecostais. Para tal, Gunnar Vingren e Daniel Berg usavam, com muita frequência, citações do livro de At 2 (Atos 2), que relata acerca do batismo com o Espírito Santo e de línguas de fogo, elementos de fé do crente assembleiano naquela época e nos dias mais atuais.

Ainda de acordo com Costa (1985), a notícia de que muitas pessoas estavam sendo curadas de males e batizadas no Espírito Santo espalhou-se rapidamente, por toda a região de Belém; muitos, então, iam aos cultos para conhecer detalhes sobre a nova unção apregoada por aqueles missionários. Em relação ao exposto, existe a hipótese de que as pessoas que frequentavam essa Missão compreenderam e defenderam a ideia de que não se resumia mais, em apenas, uma Missão, mas de uma Assembleia, tendo em vista tratarse, daquela fase em diante, de uma grande reunião de pessoas. Por isso, resolveram no dia 11 de janeiro de 1918 denominarem e constituírem, oficialmente, a Igreja Evangélica Assembleia de Deus, que, na atualidade, de acordo com o Instituto Brasileiro de Geografia e Estatística - IBGE, no Censo 2010, é a igreja evangélica que concentra o maior número de fiéis no Brasil, isto é, mais de doze milhões de pessoas.

\title{
3. Os efeitos metafóricos na Análise do Discurso de linha francesa
}

Este trabalho adota a compreensão da metáfora enquanto efeito metafórico, tal como defendido por Pêcheux:

\begin{abstract}
chamaremos efeito metafórico o fenômeno semântico produzido por uma substituição contextual para lembrar que esse "deslizamento de sentido" entre x e y é constitutivo do "sentido" designado por x e y; esse efeito é característico dos sistemas linguísticos "naturais", por oposição aos códigos e às "línguas artificiais": em outros termos, um sistema "natural" não comporta uma metalíngua a partir da qual seus termos poderiam se definir: ele é por si mesmo sua própria metalíngua. (PECHEUX, 1990, p. 96)
\end{abstract}

Pêcheux (1990) traz a metáfora como efeito de sentido instaurado por meio da posição do sujeito (social, cultural, histórico), da relação com a ideologia, com a memória discursiva e a rede de sentidos tecida pelo interdiscurso. Esse efeito metafórico relacionase fortemente com o imaginário do sujeito do discurso que, por ser social, encontra-se ancorado na formação discursiva em que se inscreve como sujeito; não em um imaginário individualizado, como é o da retórica. De modo que as transferências ou superposições que estão na base do efeito metafórico refletem todo o jogo de possíveis do discurso.

É a possibilidade do efeito metafórico, conforme afirma Pêcheux (1990), que permite que um efeito semântico possa ser substituído contextualmente por outro, sem que dele se desvincule totalmente. É, pois, esse efeito que traz a possibilidade de deslocamento dos sentidos, senão, o que ocorreria seria apenas uma reprodução dos sentidos, na qual interpretação, deslizes, deslocamentos não teriam lugar, pois seriam meras repetições do que, no caso deste trabalho, o discurso religioso já instaurou. Pêcheux defende em seus estudos que todo enunciado é intrinsecamente suscetível de tornar-se outro, diferente de si mesmo, de se deslocar discursivamente de seu sentido para derivar- 
se para outro: assim é o efeito metafórico que expõe a relação da língua e da historicidade no discurso, através dos deslocamentos de sentidos.

Pêcheux (1990) postula um conceito de metáfora como o cerne da produção de sentidos. Desse modo, para ele, os processos metafóricos são vistos como um mecanismo presente em todo processo de produção de sentidos. Desta feita, a metáfora é compreendida a partir da noção de "transferência", o modo como as palavras significam. Nessa perspectiva, não há sentido sem metáfora, como bem defendeu Pêcheux:

o sentido é sempre uma palavra, uma expressão ou uma proposição por uma outra palavra, uma outra expressão ou proposição; esse relacionamento, essa superposição, essa transferência (meta-phora), pela qual elementos significantes passam a se confrontar, de modo que se "revestem de um sentido" não poderia ser predeterminado por propriedades da língua, pois isso seria admitir que os elementos já estão dotados de sentido, que têm primeiramente sentido ou sentidos, antes de ter um sentido. De fato, o sentido existe exclusivamente nas relações de metáfora (realizadas em efeitos de substituição, paráfrases, sinônimos), das quais uma formação discursiva vem a ser historicamente o lugar mais ou menos provisório. (PÊCHEUX, 1988, p. 263)

De acordo com Orlandi (2005), é por meio da transferência de sentidos de uma palavra que percebemos a não-evidência, a não-literalidade desses sentidos, pois, para ela, palavras iguais podem significar diferentemente porque se inscrevem em formações discursivas diferentes. A partir da noção de formação discursiva, relaciona-se a questão do discurso com o próprio sujeito, ou seja, os enunciados não existem em "si mesmos", mas são determinados pelas posições ideológicas ocupadas pelo sujeito, e assim a mesma palavra pode significar de forma diferente a partir da posição em que se inscreve. É nesse ponto que o efeito metafórico, visto como processo semântico produzido por uma substituição contextual, provoca um "deslizamento de sentido" entre dois termos. Esse deslizamento ocorre porque os sentidos de um discurso são determinados pelo processo de produção e pelas condições de produção desse discurso, o que significa inscrever os sentidos na história.

A possibilidade da metáfora entendida como transferência, substituição, não é um desvio ou um erro de interpretação da história, ela é constitutiva do próprio sentido, ela promove o sentido novo e, ao mesmo tempo, carrega nele a memória do que foi dito e do que se instituiu como a gênese dos interesses que inauguraram, no caso desse trabalho, uma aproximação/contraposição entre o sagrado e o profano, o divino e o satânico. Recapitulando: Pêcheux (1969) ratifica que todo processo de produção de discursos se dá pelo constante deslizamento de sentidos, através do qual, de um termo ou expressão, passa-se a outros, que os substituem. Por essa compreensão, as metáforas devem ser entendidas não como desvios, mas como deslize ou transferência. 


\section{A heterogeneidade enunciativa e a discursiva}

Orlandi (2001) destaca que o discurso é heterogêneo porque agrega em seu interior diferentes posições-sujeito, tendo em vista que a univocidade não é parte formativa de todo e qualquer dizer. Logo, ele é composto por diversas vozes que exprimem o dialogismo como componente presente. Nessa compreensão, todo dizer é determinado de fora, do exterior, do dialógico que lhe dá constituição. Por isso, crê-se que o que se enuncia estará sempre moldado por enunciados anteriores, aos quais eles estão respondendo, e, também, por subsequentes, que eles antecipam, pois, como atesta a autora, os enunciados serão sempre compostos por elementos de outros enunciados.

Desta feita, entende-se que o discurso não se origina no momento de sua produção, mas corresponde à retomada de dizeres que estão em outros lugares e nele se acomodam produzindo efeito de homogeneidade. Logo, no estudo do discurso, deve-se ter como pressuposto a noção de heterogeneidade, o que se torna compreensível a partir da seguinte consideração:

sob nossas palavras, ressoam palavras-outras, palavras de outros sujeitos, pois o discurso é da ordem do repetível e essa repetição não remete, apenas, àquilo que foi dito anteriormente pelo sujeito do discurso, no presente ou no passado. O repetível é da ordem de um já dito mais amplo e disperso, que remete para o dizer de outros sujeitos, em outros discursos, em outros espaços e em tempos diversos, que tanto podem estar inscritos na mesma Formação Discursiva do sujeito que enuncia quanto em outra Formação Discursiva, seja ela "amigável" ou antagônica. (INDURSKY, 2001, p. 27-28)

Do exposto, nesse aspecto, vários autores têm se direcionado a essa percepção acerca da heterogeneidade discursiva. Authier-Revuz (2004) em seus estudos relacionados à linguagem efetuou a distinção de dois tipos de heterogeneidade: a heterogeneidade mostrada (marcada ou não-marcada) e a constitutiva da enunciação. Nesse ponto, podem-se observar, abaixo, as distinções feitas pela autora acerca da heterogeneidade mostrada e constitutiva, considerando-se sempre em perspectiva a produção da enunciação:

\section{a) A heterogeneidade mostrada}

Por heterogeneidade mostrada, Authier-Revuz (2004) compreende a presença do outro no discurso de um determinado locutor, ou seja, designando-o no ato de enunciação. Quando este outro é linguística e explicitamente notado, temos a heterogeneidade mostrada marcada. Como exemplos, podemos citar a glosa, as aspas, o itálico, as referências. Quando a heterogeneidade mostrada não é explicitamente detectável na materialidade da língua, a heterogeneidade mostrada é não marcada. Isso acontece no discurso indireto livre, na alusão, na imitação, na ironia, por exemplo.

b) A heterogeneidade constitutiva

A heterogeneidade constitutiva é característica essencial à enunciação. Ela possui o entrelaçamento de várias vozes e não depende de traços que sejam recuperáveis na superfície do texto, visto que o diálogo que ocorre entre os discursos não é definido, não é mostrado. Assim, por vezes, o autor do texto não tem o controle sobre essas vozes por causa das restrições sócio-histórico-culturais. 
Orlandi começa a cunhar o conceito de heterogeneidade discursiva nos anos 1980, antes mesmo da perspectiva enunciativa de Authier-Revuz. Orlandi (2006) afirma que o discurso é "caracterizado duplamente pela dispersão: a dos textos e a do sujeito" (p. 53). Com isso, a autora salienta que há várias posições-sujeito em um texto. Nesse aspecto, compreende-se que não há discurso nem sujeitos que não sejam heterogêneos, tendo essa heterogeneidade a característica de não ser localizável, nem representável no discurso que a constitui; por isso, é oposta à heterogeneidade mostrada como representação e delimitação de um sujeito/discurso na pluralidade dos outros.

Vale salientar que Authier-Revuz (2004) formula e desenvolve o conceito de heterogeneidade enunciativa; e Orlandi (2008) mobiliza a concepção de heterogeneidade discursiva, encontrando-se, portanto, em ordens diferentes: a enunciativa e a do discurso, já que a última enfatiza mais a constituição do sentido, ou seja, a própria historicidade. Para tanto, marca a sua posição, ao concluir que um texto pode ser atravessado por diferentes formações discursivas. Orlandi ultrapassa a concepção de heterogeneidade discursiva, ao verificar que, na primeira dimensão, a da enunciação, há um apagamento também, na ordem do silêncio. Sobre esta noção, a autora tem vários trabalhos, que, por ora, não serão referidos nesse texto.

É pertinente ressaltar que este trabalho assume a concepção de heterogeneidade discursiva proposta por Orlandi (2005), em que o outro sempre permanece no interdiscurso. Portanto, verifica-se a presença de diferentes discursos que constituem um determinado discurso que se pretende compreender.

\section{Aspectos metodológicos}

O universo da pesquisa foi constituído por 2 (dois) sujeitos, do sexo feminino, apresentando idades de 31 e 58 anos. Para a efetivação da pesquisa, no processo de constituição do corpus, no que se refere à modalidade técnica, a opção foi por entrevistas semi-estruturadas realizadas com os dois sujeitos envolvidos na pesquisa. Nesse item, levando-se em consideração que essa investigação não prioriza a exposição da identidade dos sujeitos entrevistados, e sim, a questão pesquisada, no momento em que os discursos forem cotejados, os referidos sujeitos serão cognominados: CMAD1 e CMAD2 (Crente Membro da Assembleia de Deus 1 e Crente Membro da Assembleia de Deus 2). É pertinente ressaltar que os dois sujeitos envolvidos responderam, espontaneamente, a um roteiro de entrevista com as perguntas abaixo:

1. Há quanto tempo você frequenta a Assembleia de Deus?

2. Para você, o que significa ser evangélico?

3. E o que significa ser evangélico da Assembleia de Deus?

4. O que a Bíblia representa para você?

5. O que o crente precisa fazer para ser salvo?

6. O crente da Assembleia de Deus é diferente? Por quê?

7. Em sua opinião, o que você precisa fazer para ser reconhecido como um crente assembleiano? 


\section{Trabalho analítico num corpus discursivo}

De acordo com Orlandi (1987, p. 139-140), “o recorte é uma unidade discursiva: fragmento correlacionado de linguagem - e - situação [...] os recortes são feitos na (e pela) situação de interlocução, aí compreendido um espaço menos imediato, mas também de interlocução, que é o da ideologia". Assim, seguem, abaixo, os recortes discursivos analisados:

— "Eu comecei a servir a Deus desde quando eu era novinha. Minha mãe me levava pra igreja e me ensinou o caminho do evangelho e desde lá eu, eu nunca me afastei, eu continuei andando na luz até hoje". (CMAD1).

— "Deus fala mesmo, muitas vezes a gente chega na igreja com um problema, sabe? Muitas vezes a gente tá no deserto mesmo, as portas tão todas fechadas, mas Deus fala com a gente e promete que vai abrir a porta pra gente e tirar a gente desse estreito, né? Isso é muito bom mesmo". (CMAD2).

Ao se observar o discurso apresentado por CMAD1, percebe-se que a heterogeneidade discursiva, proposta Orlandi (2005), está presente quando se realizam os efeitos metafóricos, pois, dão-se, a partir do interdiscurso bíblico, já que a Bíblia diz, no livro de Jó 8, 12: "Eu sou a luz do mundo". Logo, há um deslizamento de sentidos, pois sendo ele a luz do mundo, CMAD1 traz ao seu discurso um novo efeito de sentido, ao dizer que continua andando na luz até hoje. Assim, sugere que anda no caminho claro que conduz a Deus, a verdade absoluta, ao discurso verdadeiro, ideal.

Logo, é provocado um efeito metafórico, ao se reportar ao discurso bíblico, pois sendo Jesus, o caminho, os assembleianos, por serem cristãos, devem andar nesse caminho, uma vez que a memória discursiva cristã diz que esse caminho leva ao discurso perfeito, à verdade, à salvação em Deus. É desse modo que o discurso de CMAD1 é marcado pela presença do discurso divino (ideal). Aparece, aí, a heterogeneidade discursiva, proposta por Orlandi (2005). Contudo, é fundamental entender que tudo isso ocorre porque CMAD1 começou a servir a Deus "desde novinha". Observa-se que a posição-sujeito de CMAD1 é de servir.

No discurso de CMAD2 é mostrada a ênfase na voz de Deus, que marca seu discurso. Há pistas linguísticas que afirmam a crença na voz divina, com o uso do termo: "mesmo"; assim, é dito "Deus fala mesmo", bem como, noutro momento do discurso, uma expressão adversativa, "mas", fornece outra pista: "mas Deus fala com a gente". Nesse item, recorre-se à exterioridade, a algo dito noutro lugar, acerca de quem é Deus, numa relação de heterogeneidade discursiva, pois há uma memória na historicidade de quem é Deus para os cristãos, para os assembleianos. O dito, colocado contra o não dito, revela o que não aparece explicitamente. Há, também, efeitos metafóricos, ao se dizer: "Deus promete que vai abrir a porta pra gente e tirar a gente desse estreito, né". Assim, CMAD2 demonstra que a ação divina de abrir a porta não é vista, apenas, como um meio de passagem, mas provoca o efeito de sentido de livrá-la do estreito, de uma situação apertada, dificultosa, dos problemas que o crente assembleiano passa na vida cristã secular. 
Orlandi (2001) compreende que o discurso é um objeto histórico-social, cuja singularidade está em sua materialidade; os sentidos vão reproduzir características, particularidades e implicações pertencentes ao seu acontecimento. É por isso que, noutro momento, CMAD2 diz: "muitas vezes a gente tá no deserto mesmo". Dessa forma, demonstra no seu discurso os efeitos metafóricos provocados pela heterogeneidade discursiva com o interdiscurso bíblico, pois na Bíblia, o deserto foi lugar de provação de Jesus e de Moisés. Desse modo, a memória discursiva cristã resgata personagens bíblicos que estiveram no deserto. Contudo, quem afirma, na situação de entrevista, estar no deserto é um crente assembleiano; não se trata, apenas, de um relato antigo no livro de fé mais lido pelos cristãos em todo o mundo, trata-se de uma ressignificação: um crente assembleiano que vive em Pernambuco, no Brasil, noutra posição-sujeito que está no deserto, colocado por Deus ou pela voz de Deus, pois CMAD2 diz que Deus vai falar com ele e abrir a porta. Isto é, livrá-lo de determinada situação. Há um deslizamento de sentidos, pois ele, de fato, não está no deserto, mas enquanto posição-sujeito de cristão está nessa posição de provação, de passar por dificuldades, a qual é necessária para que ouça a voz de Deus. Diante disto, CMAD2 faz ressoar um efeito de apreciação valorativa de ser considerado muito bom esse contato estabelecido com o divino, com a voz de Deus, mostrando, assim, sua posição de receber a completude pela voz divina.

Do que foi mostrado, nesses recortes discursivos, acima, observa-se que Deus (Jesus, Espírito Santo) ocupa uma posição-sujeito que o faz ser visto como o grande sujeito, que é o dono do discurso correto, perfeito. Esse discurso, intocável, inquestionável, atravessa e controla o discurso dos sujeitos assembleianos, assujeitandoos. Desse modo, esse discurso ideal, advindo de uma autoridade absoluta, é materializado nos textos bíblicos, que, por sua vez, passam a estar presentes nas relações estabelecidas entre esses sujeitos assembleianos, por meio da heterogeneidade discursiva, numa relação com a memória e produzindo efeitos metafóricos.

Para enfatizar o que foi dito acima, é condizente observar, em outros dois recortes discursivos, dispostos abaixo, o modo como Deus é constituído no discurso religioso dos sujeitos assembleianos:

— "Eu mesma já fui escrava do pecado quando eu vivia no mundo, mas, graças a Deus, hoje eu procuro fazer a vontade do pai". (CMAD2).

- "Eu procuro sempre ser um vaso nas mãos dele. Algumas irmãs minhas já foram pra Glória, já estão em Jerusalém e eu continuo aqui, fazendo a vontade do Pai, né? Fazendo a vontade do Grande". (CMAD1)

Percebe-se, nos recortes discursivos acima, que tanto CMAD2 quanto CMAD1 veem a posição divina como a de um pai. Nota-se que a constituição da imagem paternal está condizente com a memória social para o lugar de pai, que, de certa forma, goza de autoridade para requerer algum posicionamento dos filhos. Isto é, a obediência. Assim, a memória social reproduz sentidos de autoridade para a posição-sujeito em família. $\mathrm{O}$ sentido produzido para a relação pai/filho está pautado na hierarquia, pois o filho não está ocupando uma posição-sujeito semelhante àquela do pai; assim, a relação hierárquica não é quebrada. É notório pontuar, na referência a Deus como pai, a presença da heterogeneidade discursiva, pois na Bíblia, Jesus, antes de morrer, disse: - "Pai, nas tuas mãos entrego o meu espírito" (Lc 23, 46); e, na posição de sujeito-crente, eles têm acesso a esse discurso bíblico, também, por meio do discurso dos pastores durante os sermões 
realizados na igreja. Há, assim, um novo efeito de sentido, pois se Jesus chamou a Deus de pai, logo, sendo o crente assembleiano filho de Deus, deve-se posicionar nessa relação familiar de pai e filho. CMAD1 ainda descreve Deus em seus dizeres como: "O Grande". Assim, não se trata, apenas, de um pai, mas um pai Grande, o maior de todos os pais.

Destacam-se, também, os efeitos metafóricos produzidos nos discursos que significam os dizeres de (CMAD1) e de (CMAD2), pois, no primeiro caso, a confiança de obedecer ao pai prodiz um deslize de sentido em relação ao objeto vaso, ao dizer que se procura ocupar a posição de vaso, estando nas mãos do pai. Logo, o pai tem a liberdade para mexer no vaso e enchê-lo como considerar oportuno. Desse modo, o filho aguarda, passivamente, o preenchimento do vaso, assim como espera pela completude que será fornecida por esse pai. No segundo caso, o efeito de sentido é produzido pela relação que se estabelece entre mundo/escravidão, vontade do pai/liberdade, pois, ao se fazer a vontade do pai, o filho não vive a posição de escravo do mundo. Isto é, não está preso, não sofre o julgo da escravidão, trabalho. Desse modo, percebe-se que na posição-sujeito ocupada por CMAD1 e por CMAD2, Deus é visto numa relação familiar e a igreja é vista como uma família, sendo Deus o pai, os crentes os filhos.

Concomitantemente aos tópicos já apontados, nas questões relativas à conversão, a fé, aos usos e costumes e ao divino e ao profano, é notório mostrar como a Bíblia aparece no discurso dos sujeitos entrevistados, estando a todo o momento presente como o discurso divino que marca o discurso desses sujeitos assembleianos, controlando-os e favorecendo, nesta relação de heterogeneidades, a produção dos efeitos metafóricos. Para tanto, torna-se pertinente exemplificar por meio da observação e descrição dos recortes discursivos extraídos das entrevistas, assim dispostos:
— "O quarto homem nos chamou pra luz, pra gente seguir ele, pra, é, fazer a vontade do pai. A gente é ovelha, né"? (CMAD1)
- "Precisa se colocar sempre na presença de Deus, eu mesma procuro ser uma mulher de mistério com Deus, uma Ester ou uma Ana, mulher de oração, como tá escrito lá na palavra. Ana era mulher de oração". (CMAD2)

Percebe-se, no dizer de CMAD1 e de CMAD2, que o interdiscurso bíblico retomado reconstrói o já-dito e nele se inscreve um novo dizer, a partir da memória discursiva de quem são os personagens bíblicos Ester, Ana e o Quarto Homem. e o que representam na memória discursiva. Ester é apresentada no relato bíblico, que é aceito e é motivo de fé desses crentes assembleianos, como tendo sido uma mulher corajosa, sábia e humilde, bem como, a rainha mais importante que Israel já teve. Judia e órfã, ela foi criada por um parente. Quando se casou com o rei Assuero, Ester fez de tudo pelo povo judeu; ela descobriu um plano para exterminar todos os judeus, por isso, preparou-se espiritualmente com um jejum de três dias e orações. Ao final do período, Ester revelou ao rei que era judia e conseguiu salvar seu povo (Est 7). Assim a Bíblia a descreve e assim os crentes assembleianos com se identificam com tal descrição.

Ana também é apresentada no relato bíblico com uma mulher virtuosa, de oração a Deus; assim, certo dia, ela orou tanto a Deus que foi tida como embriagada pelo profeta Eli, porque ela orava muito concentrada e com toda a intensidade de sua alma, de modo que só os seus lábios se mexiam. Ao perceber sua contrição a Deus, o profeta lhe concedeu o desejo de sua oração e lhe abriu a madre para que ela tivesse um filho, Samuel (1 Sm 
1). Já o quarto homem faz parte da memória discursiva evangélica como o próprio filho de Deus, Jesus, pois, na Bíblia, três jovens chamados de Sadraque, Mesaque e Abde-Nego foram jogados na fornalha de fogo ardente, pelo rei Nabucodonosor, porque eram fiéis a Deus e não se prostravam diante dos deuses pagãos, contudo, eles foram vistos passeando no meio do fogo da fornalha sem nenhum dano, pois, com eles estava presente o quarto homem, vestido de branco; o rei, quando os viu, disse que o quarto homem era semelhante ao filho de Deus (Dn 3).

Portanto, o trajeto do sentido, que o discurso nos dizeres de CMAD1 e de CMAD2 assume, só poderá ser reconhecido e interpretado quando se explicita os sentidos exteriores ao texto, recuperando-lhes a historicidade. Dessa forma, o discurso religioso de CMAD1 e de CMAD2 é produzido e circula, desse modo, em meio assembleiano, porque, de acordo com Pêcheux (1969), é a memória discursiva que torna possível a toda formação discursiva fazer circular formulações anteriores, já enunciadas. Ou seja, a memória discursiva diz respeito à recorrência de enunciados no discurso, ela separa e elege, dentre os elementos de uma determinada contingência histórica, aquilo que deve ser rejeitado e o que pode emergir e ser realizado, produzindo novos efeitos. Nesse ponto, tanto CMAD1 quanto CMAD2 demonstram, em sua posição-sujeito de crente assembleiano, uma identificação com a posição ocupada por esses personagens bíblicos, de serem crentes de orações e jejuns, sábios e tementes a Deus, de uma prática social constituída pela oração, jejuns, temência e obediência aos ensinamentos de Deus.

Em relação à proposição exposta no discurso de CMAD1 e de CMAD2 compreende-se que há um deslize de sentidos, pois é dito que "o quarto homem nos chamou pra luz". Isto é, o quarto homem que livrou na Bíblia, há mais de dois mil anos, passa, na atualidade, a chamar o crente assembleiano para luz. Há, aí, um efeito metafórico, pois a luz na memória discursiva assembleiana, acionada pelo interdiscurso bíblico, é recuperada como Jesus, logo, Jesus passa a chamar o crente assembleiano para si. De modo semelhante, tem-se a afirmação de ser uma Ana ou uma Ester ou até mesmo uma ovelha, o que produz deslizamento de sentidos e efeitos metafóricos, pois, não se pode ser, de fato, Ana, Ester ou uma ovelha; contudo, pode identificar-se com a mesma posição-sujeito de ser crente de orações e jejuns, sábios e obedientes a Deus e que precisam de cuidados do pastor das ovelhas (Deus, Jesus, Espírito Santo, Pastor).

Nesse trâmite, torna-se relevante observar que, tanto no discurso de CMAD1 quanto no discurso de CMAD2, há uma demonstração de que ambos estão na posiçãosujeito que comporta a fé vivenciada. Quer dizer, não se conceitua a fé teologicamente, mas, ela é incluída no processo religioso vivenciado: "a gente é ovelha, né"? ou "eu mesma procuro ser uma mulher de mistério com Deus, uma Ester ou uma Ana".

Outrossim, há a presença do discurso autoritário bíblico por meio da heterogeneidade discursiva, do diálogo com o discurso bíblico, que fica evidenciada através de uma pista linguística, marcada no dizer: "mulher de oração". Isto é, não se trata de qualquer Ana ou Ester, mas de ser a mulher da posição-sujeito Ana ou da posiçãosujeito Ester, aquela da Bíblia: mulheres que ocupam na memória discursiva assembleiana a posição-sujeito de mulheres de orações, portanto, não há possibilidades de dialogismo, pois a Bíblia é vista como a voz de Deus, portanto, autoritária, como já foi mostrado nessa exposição. Portanto, deve-se seguir a Bíblia, pois, é a portadora do 
discurso perfeito, ideal; não seguir esse discurso ideal é considerado pecado no meio religioso assembleiano.

Tais considerações expostas ganham mais visibilidade ao se observar, ainda, os seguintes recortes discursivos.

— "Que também tem moços que se deixam levar por causa das Dalilas do mundo e tudinho acabam pecando, viu? É mesmo assim, varão". (CMAD1)

- "Porque o anjo do Senhor acampa-se ao redor dos que o temem e os livra, sabe? O homem de branco continua dando livramento ao seu povo, do mesmo jeito que ele livrou Daniel da cova dos leões e livrou aqueles jovens da fornalha de fogo ardente, né? (CMAD2)

No discurso de CMAD1, há, mais uma vez, a presença da heterogeneidade discursiva, tal como proposta por Orlandi (2005), no diálogo com o discurso bíblico. Contudo, essa relação só pode ser estabelecida pela memória discursiva de quem é Dalila, presente, em seu discurso, pela interdiscursividade bíblica (Jz 16).

Nesse viés, Dalila, do hebraico Delilah, surge, na Bíblia, como uma das mulheres de Sansão, uma das figuras bíblicas de maior relevo. Dalila era filisteia, natural do vale de Sorec, no Norte da Filisteia. Tendo aceitado um suborno dos príncipes filisteus para que descobrisse o segredo da força de Sansão, por três vezes este lhe deu informações falsas. Mas, na quarta vez, ela conseguiu convencê-lo a revelar-lhe seu segredo: se o seu cabelo fosse cortado, perderia toda a sua força. Dalila mandou então um homem cortar o cabelo de Sansão enquanto este dormia, entregando-o, em seguida, aos filisteus.

Dito isso, os procedimentos externos e internos de circulação do discurso de CMAD1 favorecem a produção do efeito metafórico, marcado no dizer: — "Que também tem moços que se deixam levar por causa das Dalilas do mundo". Assim, há um deslize de sentidos da Dalila do discurso bíblico para as "Dalilas do mundo". Como compreendeu Pêcheux (1988), ao afirmar que todo processo de produção de discursos se dá pelo constante deslizamento de sentidos, através do qual de um termo ou expressão se passa a outros, que os substituem, ocorre na referida formulação uma ressignificação, pois, embora se trate da mesma palavra Dalila, a transferência de sentidos mostra a nãoevidência, a não-literalidade desses sentidos, conforme pontuou Orlandi (2005), ao dizer que é por meio da transferência de sentidos de uma palavra que percebemos a nãoevidência, a não-literalidade desses sentidos, pois, palavras iguais podem significar diferentemente porque se inscrevem em formações discursivas diferentes.

Aqui, tais características assumem efeitos de sentidos, por conta de novas condições de produção, pois passa a haver uma pluralidade de Dalilas no mundo. Isto é, são várias mulheres, em outras posições-sujeito, que influenciam, no dia a dia, os atuais jovens da Igreja Evangélica Assembleia de Deus a se e desidentificarem e assumirem outra posição-sujeito, vista por CMAD1, em sua posição-sujeito de crente assembleiano, como pecado, algo que desagradaria a Deus, contrariando, portanto, o discurso correto, ideal, autoritário.

A heterogeneidade presente no discurso de CMAD2 se configura como discursiva, pois não se recupera na superfície do texto, como, por exemplo, tomando-se o dizer "o 
homem de branco continua dando livramento..." ou "livrou aqueles jovens da fornalha de fogo ardente", ou ainda, "do mesmo jeito que ele livrou Daniel da cova dos leões". Do exposto, pode-se perceber que o interdiscurso, presente nesses recortes discursivos citados, denuncia que o discurso desses sujeitos assembleianos é atravessado por diferentes formações discursivas referidas na posição-sujeito dos diversos personagens bíblicos. Vale destacar que, embora saibamos que há também a presença de outros discursos, além do discurso bíblico, atravessando o discurso desses sujeitos assembleianos, como, por exemplo, o machista, este trabalho se destinou a apontar para o atravessamento do discurso bíblico, por ser a Bíblia o principal livro de identificação do crente assembleiano pelo modo como, por esse dizer, inscreve-se na formação discursiva que o significa enquanto crente assembleiano. Contudo, é pertinente destacar que a Bíblia não é citada neste trabalho como um livro científico nem como axioma, mas como elemento presente no discurso pentecostal desses sujeitos cujos dizeres foram tomados para análise na pesquisa.

É interessante observar, nos recortes discursivos acima, o modo como a memória discursiva é acionada, tendo em vista que o discurso bíblico acerca desses personagens bíblicos tornou-se, amplamente, conhecido no mundo, em geral, por meio de livros, peças teatrais, músicas e empresas cinematográficas, presente assim, no imaginário social. Retomando Orlandi (2005), observamos que os diferentes sentidos encontrados em diferentes enunciados remetem às memórias e às circunstâncias externas, mostrando que o sentido não está apenas nas palavras e no texto propriamente dito, mas na tensão das relações de forças, pois, os dizeres não são apenas mensagens a serem decodificadas. Assim, nos recortes discursivos analisados, o linguístico está intervindo como pressuposto, apontando para a exterioridade, para outras formações discursivas que atravessam o discurso desses sujeitos assembleianos identificados à formação discursiva de crentes assembleianos, apontando para o já-dito, conforme nos mostra Pêcheux (1969), ao dizer que alguma coisa fala antes, em outro lugar, independentemente e diferentemente. Desse modo, constituindo-se nesta relação entre paráfrase e polissemia, há o acionamento da memória discursiva, promovendo o encontro de uma atualidade e uma rede de memórias, na produção de sentidos constituída pela historicidade.

Por fim, os próximos recortes discursivos, abaixo, mostram com mais evidência, como cada um dos sujeitos entrevistados se mostra em relação à identificação à determinada posição-sujeito e formação discursiva.

— "Tem que ser diferente, viu? Tem que ser crente de fogo, porque Jesus vai vomitar os frio e os morno, mas os crente de fogo vão pro céu, vão falar a língua dos anjos. Vão ficar face a face com o Homem de Branco, varão. Creia nisso, porque é mesmo assim, viu? Então o crente tem que, tem que ter diferença mesmo, tem que ser de oração, tem que ser vaso cheio de azeite, não pode faltar o azeite, né"? (CMAD1)

— "É viver na palavra, porque o crente tem que viver pela palavra, porque a Bíblia é a palavra Deus, né? Na Assembleia de Deus tem muita gente que se coloca nas mãos de Deus, tem muitos crentes de mistérios com Deus, crentes de fogo mesmo, sabe? Crente que gosta de orar mesmo, que busca os dons espirituais. Eu gosto de ser da Assembleia de Deus porque a gente aprende a não ter vaidade, a gente aprende a não dar valor as coisas do mundo, porque o inimigo das nossas almas 
quer que a gente se misture com o mundo, mas tá amarrado, porque Deus não se agrada disso não, sabe"? (CMAD2)

É interessante pontuar que CMAD1 diz, por meio de efeitos metafóricos, o que é ser diferente e como o crente deve ser: "ser crente de fogo" e "ser vaso cheio de azeite". Por meio da heterogeneidade discursiva, a memória discursiva aciona o interdiscurso bíblico. O fogo atualiza discursos referentes a uma prática social de oração dos discípulos, pois no livro de At 2, diz-se que "os discípulos estavam reunidos, orando, no cenáculo, no dia de Pentecostes, quando vos sobreveio um vento impetuoso e veemente que encheu todo o cenáculo e viram-se, entre eles, línguas repartidas como que de fogo".

Daí, ocorre a ressignificação no discurso de CMAD1, pois não se deve ser crente, apenas, mas o crente tem que ser de fogo. De igual modo, a Bíblia relata no livro de Jeremias, capítulo dezoito, um diálogo entre Deus e o profeta Jeremias, no qual o próprio Deus diz a Jeremias ser ele o oleiro e Jeremias o vaso. Já noutro momento, a Bíblia relata a história de uma viúva pobre ( $2 \mathrm{Rs} 4$ ), que teve seu azeite multiplicado pelo profeta Eliseu, de tal modo que todos os seus vasos ficaram cheios de azeite, numa provisão divina. Logo, o discurso de CMAD1 traz um deslize de sentido, produzindo efeitos metafóricos ao apresentar o crente assembleiano, de hoje, como um vaso cheio de azeite. Isto é, um crente cheio do Espírito Santo de Deus.

O discurso de CMAD2 também mostra, assim como no discurso de CMAD1, por meio dos efeitos metafóricos, como o crente assembleiano deve ser: "crentes de mistérios com Deus" e "crentes de fogo mesmo". Novamente, têm-se a presença do interdiscurso bíblico, acionado pela memória discursiva, que permite realizar um deslize de sentido entre o acontecimento discursivo presente no livro de At 2, sobre a oração no dia de Pentecostes, já exposto, e a atualidade, crentes de fogo assembleiano. No caso, dos "crentes de mistérios com Deus", o deslizamento de sentido se dá a partir do interdiscurso bíblico, numa heterogeneidade discursiva, pois, a Bíblia apresenta Deus como um Deus de mistério. Logo, têm-se o efeito de sentido: "crentes de mistérios".

\section{Considerações finais}

$\mathrm{O}$ artigo, aqui apresentado, trouxe discursos religiosos historicamente marcados, materializados em uma unidade discursiva que possibilita o já-dito ser inscrito em um novo acontecimento, promovendo descrições e reflexões. A partir do procedimento investigativo respaldado pela $\mathrm{AD}$, pôde-se mostrar que o sujeito assembleiano apresentase posicionado num tempo e espaço socialmente situados, na imbricação entre o linguístico e o social, levando-se em consideração que, para Pêcheux (1997), a interpretação é materializada na/pela história. Nesse viés, o acontecimento discursivo apresentou-se como um fator relevante para a interpretação.

Assim, analisar a materialidade do discurso de dado objeto é fazer com que se articule o linguístico às condições sócio-históricas, reconhecendo que os processos de produção, circulação e interpretação dos sentidos dependem da relação mantida entre o já-dito e o não-dito. Nesse viés, a relação entre língua e história faz com que os dizeres sejam demarcados por uma ordem discursiva que estabelece os limites do discurso. É por 
meio do discurso, lugar de enfrentamento teórico, que sujeitos e sentidos se constituem, assim, como compreendeu Orlandi (2001). Assim, pela perspectiva da Análise do Discurso de linha francesa, mostrou-se como a heterogeneidade discursiva está presente no discurso desses sujeitos assembleianos, como é realizada por meio do interdiscurso bíblico e das relações estabelecidas entre o discurso dos crentes da Assembleia de Deus, clivado pelo discurso divino. Desse modo, pode-se compreender que o sujeito assembleiano, interpelado pela ideologia e afetado pelo inconsciente, assume uma posição, um lugar a partir do qual produz enunciados, sendo irremediavelmente afetado por dizeres anteriores.

Dessa forma, pôde-se perceber que, no discurso dos dois sujeitos entrevistados, há o "outro" interno presente na memória discursiva evangélica, como bem salientou Pêcheux (1997), ao considerar a marca do real histórico como causa do fato de que nenhuma memória pode ser um frasco sem exterior. Assim, os efeitos metafóricos produzidos no discurso dos sujeitos assembleianos mostraram como o que é dito noutro lugar é ressignificado nesse discurso religioso, como o interdiscurso bíblico contribui para a realização de novos efeitos de sentidos.

\section{Referências bibliográficas}

AUTHIER-REVUZ, J. Entre a transparência e a opacidade - um estudo enunciativo o sentido. Porto Alegre: EDIPUCRS, 2004.

COSTA, J.M. Eles andaram com Deus. Rio de Janeiro: Ed. Casa Publicadora das Assembleias de Deus, Rio de Janeiro: 1985.

COURTINE, J.-J.; MIRANDIM, J.M. Quel object pour l'analyse du discours? Materialités discursives. Lille: Press Universitaires, 1981.

IBGE, Instituto Brasileiro de Geografia e Estatística. Censo Demográfico 2010, tabela de N. 1489 - Amostra Característica Gerais da População - Religião.

INDURSKY, F. Da heterogeneidade do discurso à heterogeneidade do texto e suas implicações no processo da leitura. Em: ERNEST-PEREIRA, A.; FUNCK, S.B. (Orgs.). A escrita e a leitura como práticas discursivas. Pelotas: Educat, 2001.

A fala dos quartéis e as outras vozes. Campinas: Unicamp, 1997.

ORLANDI, E.P. Terra à Vista. Discurso do confronto: velho e novo mundo. $2^{\mathrm{a}}$ ed. Campinas, SP: Editora da UNICAMP, 2008.

Palavra, fé, poder. Campinas: Pontes, 1987.

Discurso e leitura. $7^{\mathrm{a}}$. ed. São Paulo: Cortez, 2006.

Análise do Discurso: princípios \& procedimentos. São Paulo: Pontes, 2005. 
ORLANDI, E.P. Discurso e texto: formação e circulação dos sentidos. Campinas: Pontes, 2001.

PÊCHEUX, M. [1969]. Análise automática do discurso. Em: GADET, F.; HAK, T. (Orgs.). Por uma análise automática do discurso. Campinas: Ed. da Unicamp, 1993.

; FUCHS, C. A propósito da análise automática do discurso: atualização e perspectivas (1975). Em: GADET, F.; HAK, T. (Orgs). Por uma análise automática do discurso: uma introdução à obra de Michel Pêcheux. Campinas: Unicamp, 1993.

(1975). Semântica e discurso: uma crítica à afirmação do óbvio. Campinas: Ed. da Unicamp, 1988.

O discurso: estrutura ou acontecimento. $2^{\mathrm{a}}$. ed. São Paulo: Pontes, 1997.

\section{$* * *$}

Artigo recebido em: abril de 2016.

Aprovado e revisado em: junho de 2016.

Publicado em: agosto de 2016

\section{Para citar este texto:}

SILVA, Dalexon Sérgio da; AZEVEDO, Nadia Pereira da Silva Gonçalves de. Efeitos metafóricos e heterogeneidade no discurso religioso de membros da Assembleia de Deus: uma análise discursiva. Entremeios [Revista de Estudos do Discurso], Seção Estudos, Programa de Pós-graduação em Ciências da Linguagem (PPGCL), Universidade do Vale do Sapucaí, Pouso Alegre (MG), vol. 13, p. 123-137, jul. - dez. 2016.

DOI: http://dx.doi.org/10.20337/ISSN2179-3514revistaENTREMEIOSvol13pagina123a137 